\title{
Pengaruh Problem Based Learning (PBL) Dalam Meningkatkan Kompetensi Mahasiswa Program Studi Pendidikan Kimia FKIP UPR Sebagai Calon Guru
}

\author{
Suandi Sidauruk \\ Program Studi Pendidikan Kimia, FKIP Universitas Palangka Raya, Indonesia \\ Email: sidauruksuandi@yahoo.co.id
}

\begin{abstract}
Abstrak: Implementasi PBL akan membantu mahasiswa dalam mengembangkan kebiasaan berpikir, bersikap, dan berperilaku yang dibutuhkan sebagai tenaga pendidik profesional yang kompeten, melayani, dan etis. Jika dilakukan dengan benar, PBL dapat memberikan sumbangan penting bagi perbaikan karakter guru. Tujuan penelitian ini adalah untuk mengembangkan skenario PBL dan mengetahui pengaruh pembelajaran PBL terhadap peningkatan kompetensi mahasiswa sebagai calon guru. Pengembangan skenario PBL dilakukan melalui logical review. Logical review bertujuan untuk menenetapkan validitas kasus dan langkahlangkah pemecahan kasus menggunakan metode seven jump. Hasil penelitian ini berupa skenario PBL untuk mata kuliah metode penelitian pendidikan kimia. Kendala utama melaksanakan pembelajaran PBL adalah pengetahuan mahasiswa terkait dengan konsep kimia sangat rendah, sehingga mahasiswa mengalami kesulitan mengidentifikasi masalah yang diajukan dalam kasus. Secara keseluruhan, mahasiswa mampu merumuskan masalah dan judul penelitian dengan benar walaupun substansi kimia yang diteliti belum dipahami. Pembelajaran PBL tepat diterapkan untuk mata kuliah yang kompetensi standarnya menuntut kompetensi mahasiswa memproduksi sesuatu.
\end{abstract}

\section{Kata kunci: kompetensi calon guru, metode penelitian, PBL, pereaksi pembatas}

\section{Pendahuluan}

Pengguna lulusan telah lama mendesak perguruan tinggi untuk menghasilkan lulusan dengan berbagai kompetensi atau keterampilan yang membuat lulusan segera efektif memasuki dunia kerja. Belt, dkk. (2003) menyatakan bahwa beberapa penelitian mengidentifikasi kompetensi yang harus dimiliki oleh seorang lulusan adalah kemampuan komunikasi, bekerjasama, operasi hitung, penggunaan IT, dan belajar. Kompetensi ini juga tercakup dalam kompetensi seorang guru.

Sebagai calon guru, lulusan Program Studi Pendidikan Kimia FKIP UPR harus memiliki kompetensi seorang guru, yaitu kompetensi pedagogik, sosial, kepribadian, dan profesional. Komponen kompetensi pedagogik mencakup: 1) Menguasai karakteristik peserta didik, 2) Menguasai teori belajar dan prinsipprinsip pembelajaran yang mendidik, 3) Mengembangkan kurikulum, 4) Menyelenggarakan pembelajaran yang mendidik, 5) Mengembangkan potensi peserta didik, 6) Berkomunikasi dengan peserta didik, dan 7) Menyelenggarakan penilaian dan evaluasi. 
Komponen kompetensi kerpibadian mencakup: 1) Bertindak sesuai dengan norma agama, hukum, sosial, dan kebudayaan nasional Indonesia, 2) Menampilkan pribadi yang dewasa dan teladan, dan 3) Etos kerja, tanggung jawab tinggi dan rasa bangga menjadi guru. Komponen kompetensi sosial mencakup: 1) Bersikap inklusif, bertindak objektif, serta tidak diskriminatif dan 2) Komunikasi dengan sesama guru, tenaga kependidikan, orangtua peserta didik, dan masyarakat. Komponen kompetensi profesional mencakup: 1) Kemampuan menguasai materi pelajaran secara luas dan professional dan 2) Mengembangkan keprofesionalan melalui tindakan yang reflektif dan memanfaatkan teknologi informasi dan komunikasi untuk mengembangkan diri.

Untuk mencapai kompetensi tersebut, kegiatan pembelajaran sebaiknya bersifat holistik dan mampu membangkitkan semua aspek kompetensi yang dituntut. Menurut Mackenzie \& Johnstone, \& Brown (2003), karakter PBL adalah menuntut peserta didik untuk bertanggung jawab lebih besar untuk apa dan bagaimana mereka belajar. Peran peserta didik menonjol dalam mendefinisikan masalah, mengidentifikasi kebutuhan belajar, mengorganisir, dan mengintegrasikan materi belajar dari berbagai sumber. Proses PBL memfasilitasi peserta didik belajar dalam kelompok kecil dan belajar mandiri. Kegiatan pembelajaran yang bersifat satu arah dan kegiatan praktikum yang bersifat perseorangan semakin berkurang.

John Hattie (dalam Supranata, 2012) menggunakan meta analisis untuk memperkirakan efek keseluruhan pada prestasi siswa menyimpulkan bahwa faktor yang dominan mempengaruhi prestasi siswa adalah guru (30\%) dan karakteristik siswa (47\%). Selanjutnya, Carey (2004) melaporkan bahwa guru-efektif mengajar dapat meluluskan siswa dengan kemampuan rendah (90\%), sedang (100\%), dan tinggi (100\%). Guru-tidak efektif meluluskan $42 \%$ siswa kemampuan rendah, 89\% siswa kemampuan sedang, dan $90 \%$ siswa kemampuan tinggi. Data ini menjelaskan bahwa 98\% siswa yang diajar oleh guru-efektif akan lulus dalam ujian, dan hanya $63 \%$ siswa yang lulus jika diajar oleh guru-tidak efektif. Hasil penelitian ini menjelaskan bahwa guru yang baik (memiliki kompetensi baik) sangat berpengaruh terhadap prestasi siswa.

Hasil uji kompetensi mengindikasikan sebagian besar guru memiliki kompetensi rendah. Untuk memperbaiki keadaan ini, dapat dimulai dari lembaga pendidikan tenaga pendidikan (LPTK) sebagai penghasil tenaga pendidik, yaitu melalui perbaikan kegiatan pembelajaran yang lebih berorientasi kepada mahasiswa, misalnya menerapkan PBL.

PBL pertama kali diimplementasikan di Fakultas Kedokteran Universitas McMaster, Kanada, tahun 1969, sebagai sebuah cara belajar baru yang radikal dan inovatif dalam pendidikan dokter (Gwee, 2009). Dewasa ini, PBL telah diterapkan dalam berbagai bidang pendidikan, sebagai jawaban terhadap tuntutan kompetensi lulusan. Namun, PBL belum pernah diterapkan di program studi pendidikan kimia. Oleh karena itu, keutamaan penelitian ini adalah: 1) diproduksi beberapa 
bentuk skenario sebagai bahan pelaksanaan PBL, 2) mengatahui pengaruh penerapan PBL terhadap kompetensi mahasiswa sebagai calon guru. Selain itu, penelitian ini juga berdampak bagi mahasiswa sebagai calon guru yang terlibat dalam penelitian, yaitu memperoleh pengalaman langsung dalam kegiatan PBL sehingga kelak dapat menerapkannya di kelas ketika menjadi guru.

\section{Metodologi Penelitian}

Tujuan utama penelitian ini adalah untuk mengetahui pengaruh PBL terhadap kompetensi mahasiswa Program Studi Pendidikan Kimia sebagai calon guru. Penelitian ini akan melibatkan mahasiswa Program Studi Pendidikan Kimia yang memprogram mata kuliah PHB. Rincian kegiatan penelitian disajikan pada Tabel 1.

Tabel 1. Rincian Kegiatan Penelitian

\begin{tabular}{|c|c|c|c|c|c|}
\hline Tahap & Kegiatan & Tujuan & $\begin{array}{c}\text { Teknik } \\
\text { pengumpulan data }\end{array}$ & $\begin{array}{c}\text { Instrumen } \\
\text { pengumpula } \\
\text { n data }\end{array}$ & $\begin{array}{c}\text { Teknik } \\
\text { analisis } \\
\text { data } \\
\end{array}$ \\
\hline 1. Persiapan & $\begin{array}{l}\text { - Menyusun panduan } \\
\text { PBL } \\
\text { - Menyusun lembar } \\
\text { kasus } \\
\text { - Menyusun instrumen } \\
\text { pre dan pos tes. }\end{array}$ & $\begin{array}{l}\text { Memproduksi } \\
\text { panduan PBL, } \\
\text { lembar kasus, } \\
\text { serta instrumen } \\
\text { pre dan pos tes }\end{array}$ & $\begin{array}{l}\text { Menginventarisasi } \\
\text { panduan PBL. } \\
\text { Lembar kasus, serta } \\
\text { instrumen pre dan } \\
\text { pos tes }\end{array}$ & Dokumen & Deskriptif \\
\hline 2. Pre tes & $\begin{array}{l}\text { Menguji kemampuan } \\
\text { awal mahasiswa }\end{array}$ & $\begin{array}{l}\text { Mengetahui } \\
\text { kemampuan awal } \\
\text { mahasiswa } \\
\text { sebelum } \\
\text { mengikuti PBL } \\
\end{array}$ & $\begin{array}{l}\text { Memberikan tes } \\
\text { kemapuan PHB }\end{array}$ & Tes tertulis & Deskriptif \\
\hline $\begin{array}{l}\text { 3. Pembela- } \\
\text { jaran }\end{array}$ & $\begin{array}{l}\text { - Klarifiksai } \\
\text { istilah/konsep } \\
\text { - Merumuskan } \\
\text { masalah } \\
\text { - Menganalisa masalah } \\
\text { - Menyusun hipotesis } \\
\text { - Menentukan tujuan } \\
\text { pembelajaran serta } \\
\text { menentukan cara } \\
\text { mencapai tujuan ini. } \\
\text { - Mengumpulkan } \\
\text { informasi } \\
\text { - Melaporkan hasil } \\
\text { pembelajaran }\end{array}$ & $\begin{array}{l}\text { Mengetahui: } \\
\text { - istilah/konsep } \\
\text { yang sulit } \\
\text { - kemampuan } \\
\text { merumuskan } \\
\text { masalah } \\
\text { - kemampuan } \\
\text { menganalisis } \\
\text { masalah } \\
\text { - kemampuan } \\
\text { menyusun } \\
\text { hipotesis } \\
\text { - kemampuan } \\
\text { menentukan } \\
\text { tujuan } \\
\text { pembelajaran } \\
\text { - kemampuan } \\
\text { mengumpulkan } \\
\text { informasi } \\
\text { - kemampuan } \\
\text { menyusun } \\
\text { laporan hasil } \\
\text { pembelajaran } \\
\end{array}$ & $\begin{array}{l}\text { - Menginvertarisasi } \\
\text { hasil pekerjaan } \\
\text { mahasiswa pada } \\
\text { setiap tahap } \\
\text { kegiatan PBL } \\
\text { - Mahasiswa } \\
\text { melakukan } \\
\text { presentasi }\end{array}$ & $\begin{array}{l}\text { - Dokumen } \\
\text { - Lembar } \\
\text { penilaian } \\
\text { presentasi }\end{array}$ & Deskriptif \\
\hline 4. Pos tes & $\begin{array}{l}\text { Menguji kemampuan } \\
\text { akhir mahasiswa }\end{array}$ & $\begin{array}{l}\text { Mengetahui } \\
\text { kemampuan akhir } \\
\text { mahasiswa setelah } \\
\text { mengikuti PBL }\end{array}$ & $\begin{array}{ll}\text { Memberikan } & \text { tes } \\
\text { kemapuan PHB } & \end{array}$ & Tes tertulis & Deskriptif \\
\hline
\end{tabular}


Data yang dikumpulkan pada penelitian ini berupa: pengetahuan PHB, keterampilan mengembangkan PHB, dan keterampilan mengelola hasil PHB. Ketiga data ini dijaring menggunakan tes tertulis, dokumen, serta pengamatan. Data yang diperoleh akan dianalisis menggunakan uji perbedaan untuk mengetahui efektivitas pelaksanaan PBL sebelum dan sesudah pembelajaran. Anava digunakan untuk mengetahui efektivitas PBL ditinjau dari kemampuan toeri PHB, keterampilan mengembangkan PHB, dan keterampilan mengelola PHB.

\section{Hasil Penelitian Dan Pembahasan}

Penelitian dilakukan pada periode bulan Agustus - November 2013. Penelitian ini melibatkan mahasiswa Program Studi Pendidikan Kimia Universitas Palangka Raya yang memprogram mata kuliah metodologi penelitian kimia. Jumlah mahasiswa yang terlibat sebanyak 70 orang.

Pada tahap Pra PBL, dilakukan tes untuk mengetahui pengetahuan awal mahasiswa dalam mengalisis masalah, serta menentukan judul dan masalah penelitian. Kemampuan awal ini ditelusuri menggunakan tes tertulis berupa kasus tentang kesulitan siswa SMA dalam memahami konsep kimia (pereaksi pembatas). Berikut ini disajikan soal pre tes berupa kasus:

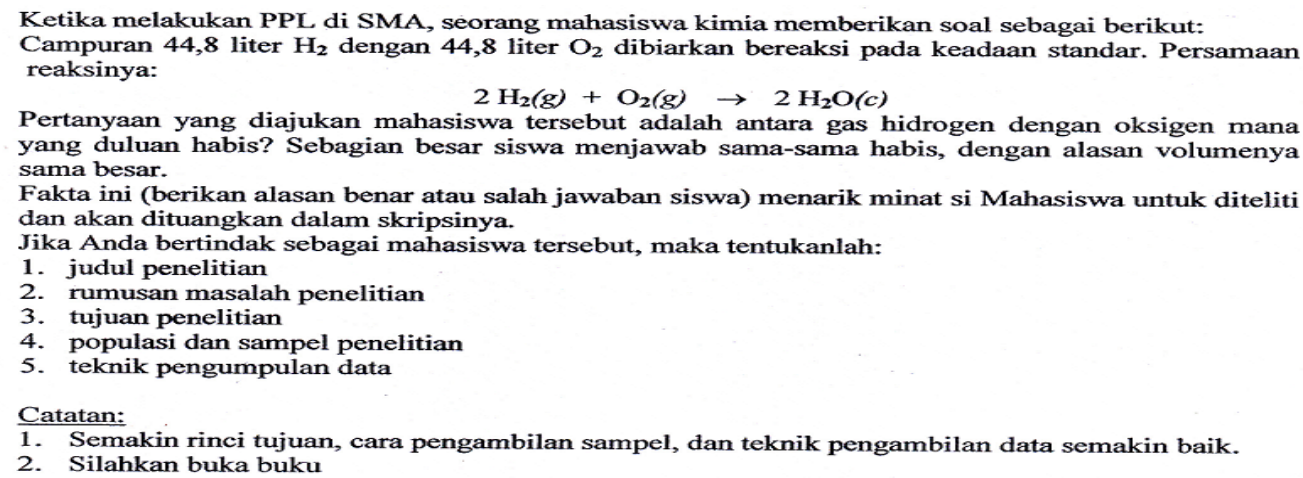

Untuk menyelesaikan kasus ini, terlebih dahulu mahasiswa menyelesaikan soal seperti dalam kasus, yaitu tentang pereaksi pembatas.

Sebagian besar (96\%) mahasiswa salah mengerjakan soal tersebut. Berikut ini disajikan tiga pola kesalahan dominan yang dilakukan mahasiswa dalam menyelesaikan soal pereaksi pembatas. 


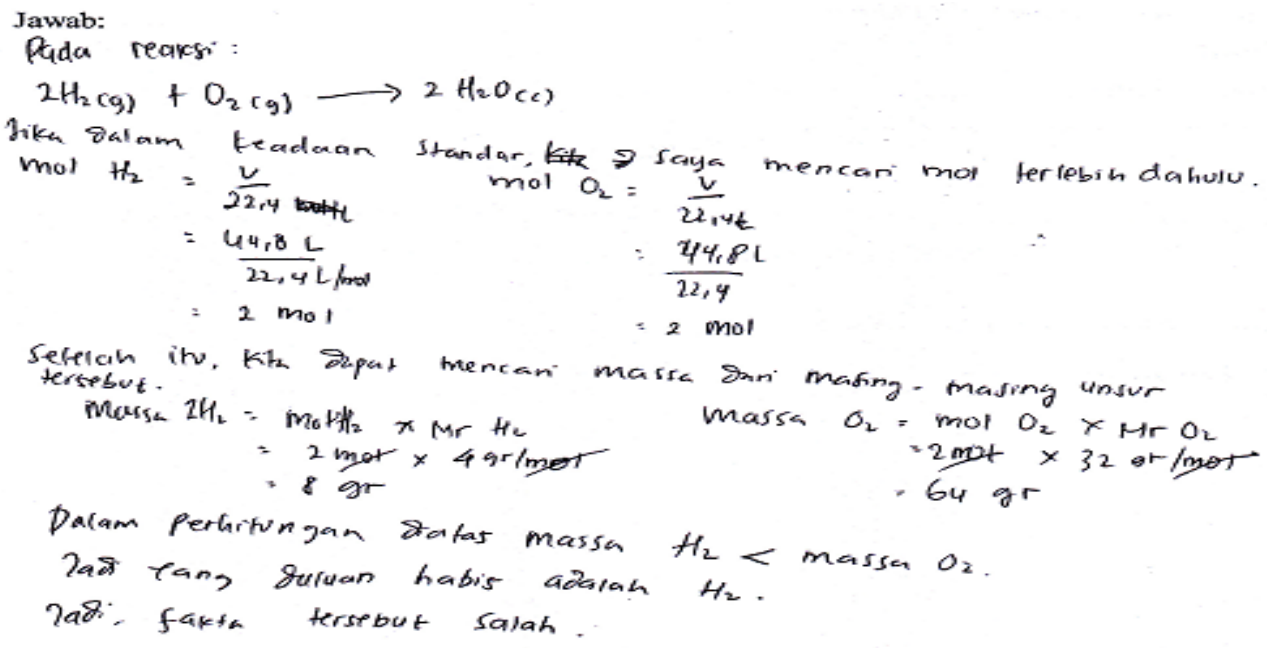

Gambar 1. Pola kesalahan 1: Pereaksi Pembatas (16\%)

Jawab:

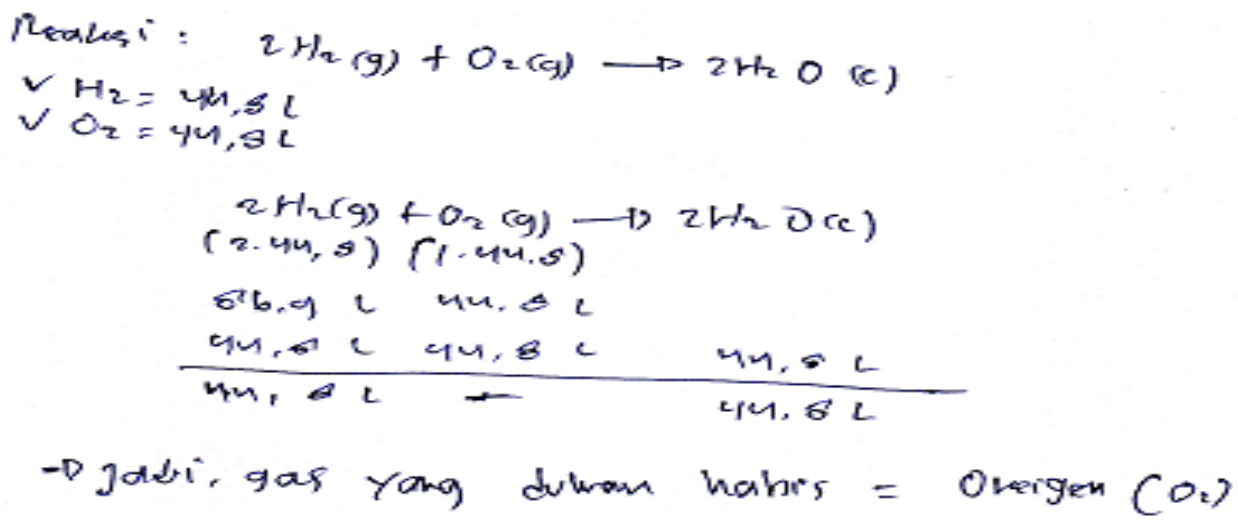

Gambar 2. Pola kesalahan 2: Pereaksi Pembatas (31\%)

Jawab:

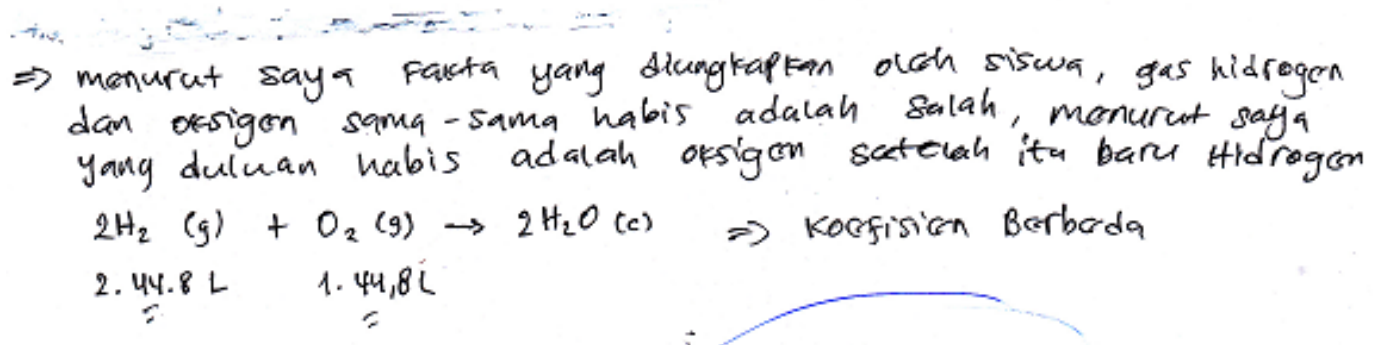

Gambar 3. Pola Kesalahan 3: Pereaksi Pembatas (53\%)

Berdasarkan pola jawaban mahasiswa di atas, dapat disimpulkan bahwa mahasiswa berpendapat "zat yang duluan habis dalam suatu reaksi kimia tergantung kepada jumlahnya, zat yang jumlahnya sedikit selalu duluan habis daripada zat yang jumlahnya lebih banyak". Jika gas hydrogen dan gas oksigen direaksikan masing-masing berjumlah 2 mol dan 1 mol, maka kedua zat ini akan 
sama-sama habis sesuai dengan perbadingan koefisiennya, meskipun massa gas hydrogen dan gas oksigen yang bereaksi berturut-turut 2 gram dan 32 gram.

Pola kesalahan 2 disebabkan mahasiswa belum memahami posisi koefisien reaksi dan zat mula-mula atau jumlah zat awal yang tersedia untuk direaksikan. Hal ini terlihat mahasiswa mangalikan jumlah zat mula-mula dengan koefisien reaksi, akibatnya jumlah gas hydrogen semakin banyak dibandingkan dengan yang tersedia. Seharusnya, koefisien reaksi digunakan untuk menentukan perbandingan jumlah zat yang bereaksi.

Pola kesalahan 3 adalah pola kesalahan yang paling dominan, yaitu zat yang memiliki koefisien pereaksi kecil selalu duluan habis beaksi daripada zat yang memiliki koefisen reaksi lebih besar. Kesalahan ini mendukung kesalahan pada pola kesalahan 1 .

Kesalahan mahasiswa terhadap penguasaan materi kimia, khususnya konsep pereaksi pembatas, berakibat kepada kesulitan mahasiswa mengidentifikasi konsep kimia dalam soal. Selanjutnya, mahasiswa kurang tajam menentukan konsep yang akan diteliti seperti tertulis pada beberapa judul berikut ini.

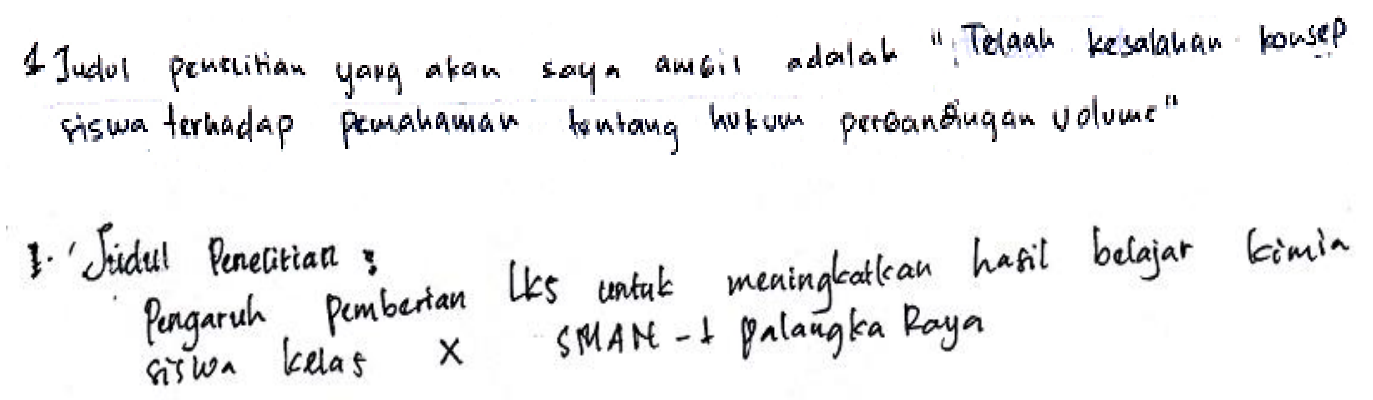

Pada tahap PBL, dilaksanakan kegiatan pembelajaran dengan menerapkan PBL. Pada pertemuan pertama, dilakukan sosialisasi pelaksanaan PBL selama pembelajaran mata kuliah metodologi penelitian kimia. Selanjutnya, kepada mahasiswa diberikan perangkat pelaksanaan PBL, yaitu: langkah-langkah melaksanakan PBL dengan metoda Seven Jump, jadwal kegiatan, dan log book. Sebelum pertemuan pertama ditutup, kepada mahasiswa diminta membentuk kelompok dengan angota minimal 5 mahasiswa per kelompok.

Pada pertemuan kedua, kepada mahasiswa diberikan kasus yang harus dipecahkan mahasiswa selama kegiatan berlangsung. Kasus yang diberikan mirip dengan kasus pada pre tes, yaitu permasalahan yang dimiliki siswa SMA dalam memahami konsep pereaksi pembatas, namun zat yang direaksikan berbeda.

Ketika melakukan PPL di SMA, seorang mahasiswa kimia, Neo, memberikan soal sebagai berikut kepada siswanya sebagai berikut:

Campuran 4 liter gas butana dengan 6,5 liter gas $\mathrm{O}_{2}$ dibiarkan bereaksi pada keadaan standar.

Jika reaksi berlangsung sempurna, manakah duluan habis antara gas butana dengan gas oksigen?

Sebagian besar siswa menjawab gas butana, dengan alasan volume gas butana lebih kecil.

Fakta ini menarik minat Neo untuk diteliti dan akan dituangkan dalam skripsinya. 
Kegiatan pembelajaran PBL pada pertemuan ini, kepada mahasiswa diminta untuk melakukan Langkah 1-5 dari Seven Jump, yaitu: klarifiksai istilah/konsep (Langkah 1), merumuskan masalah (Langkah 2), menganalisa masalah (Langkah 3), menyusun hipotesis (Langkah 4), dan menentukan tujuan pembelajaran serta cara menentukan mencapai tujuan ini (Langkah 5). Seluruh aktivitas mahasiswa direkam dalam log book.

Berdasarkan data yang tersaji dalam log book, sebagian besar mahasiswa sepakat dengan tujuan pembelajaran setelah membaca Kasus 1, yaitu:

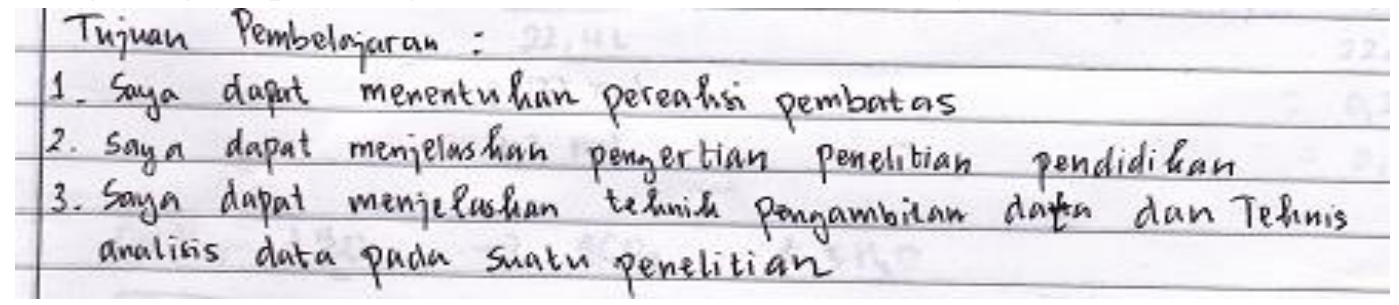

Untuk mencapai tujuan ini, mahasiswa menulis dalam log book:

\begin{tabular}{|c|}
\hline Sumber belajar : \\
\hline - Kinia unhwh helas $x$ Semester 1 Seholah menengah Atas. Penerbit Grafindo \\
\hline $\begin{array}{l}\text { Media Pratama. Nana Sultesna } \\
\text { - PdF Bahasalndonesia Panduan }\end{array}$ \\
\hline - http: // Shriksistifies. Wordpress. Com \\
\hline - Skripsi Siska Program Studi pendidikan himia, Knivesti Sas Palangharaya \\
\hline mengenai penggunaan model PBI untuh mening hathan hasil belajar \\
\hline
\end{tabular}

Data ini dapat menjelaskan bahwa mahasiswa mengalami kesulitan dalam menyelesaikan soal pereaksi pembatas sehingga perlu dituliskan sebagai tujuan pembelajaran yang harus dicapainya agar dapat memahami penelitian pendidikan kimia. Selanjutnya, untuk meningkatkan pemahaman mahasiswa terkait dengan penyusunan proposal penelitian pendidikan kimia, rujukan yang paling banyak digunakan mahasiswa adalah proposal atau skripsi penelitian pendidikan kimia. Rujukan ini tersedia di perpustakaan program studi kimia dan perpusatakaan FKIP.

Langkah 1-5, dilakukan di kelas. Selanjutnya, mahasiswa secara individu maupun kelompok berusaha mencapai tujuan pembelajaran yang telah disepakati pada Langkah 1-5. Upaya ini dilakukan dengan cara mencari sumber belajar dan diskusi kelompok di luar kelas (Langkah 6). Pada pertemuan selanjutnya dilakukan Langkah 7, yaitu berbagi hasil belajar mandiri (presentasi).

Pada Langkah 7, mahasiswa secara individu dan kelompok mengumpulkan log book yang berisi uraian kegiatan yang dilakukan selama seminggu, termasuk bahan presentasi. Kegiatan presentasi dilakukan oleh setiap kelompok. Oleh karena itu, pada Langkah 7 dilakukan selama empat kali pertemuan. Jumlah kelompok 7, setiap minggu ada dua kelompok yang melakukan presentasi. Seluruh peristiwa pada kegiatan diskusi ini dicatat oleh mahasiswa dalam log 
book. Berikut ini disajikan upaya yang dilakukan mahasiswa dalam menyelesaikan soal pereaksi pembatas.

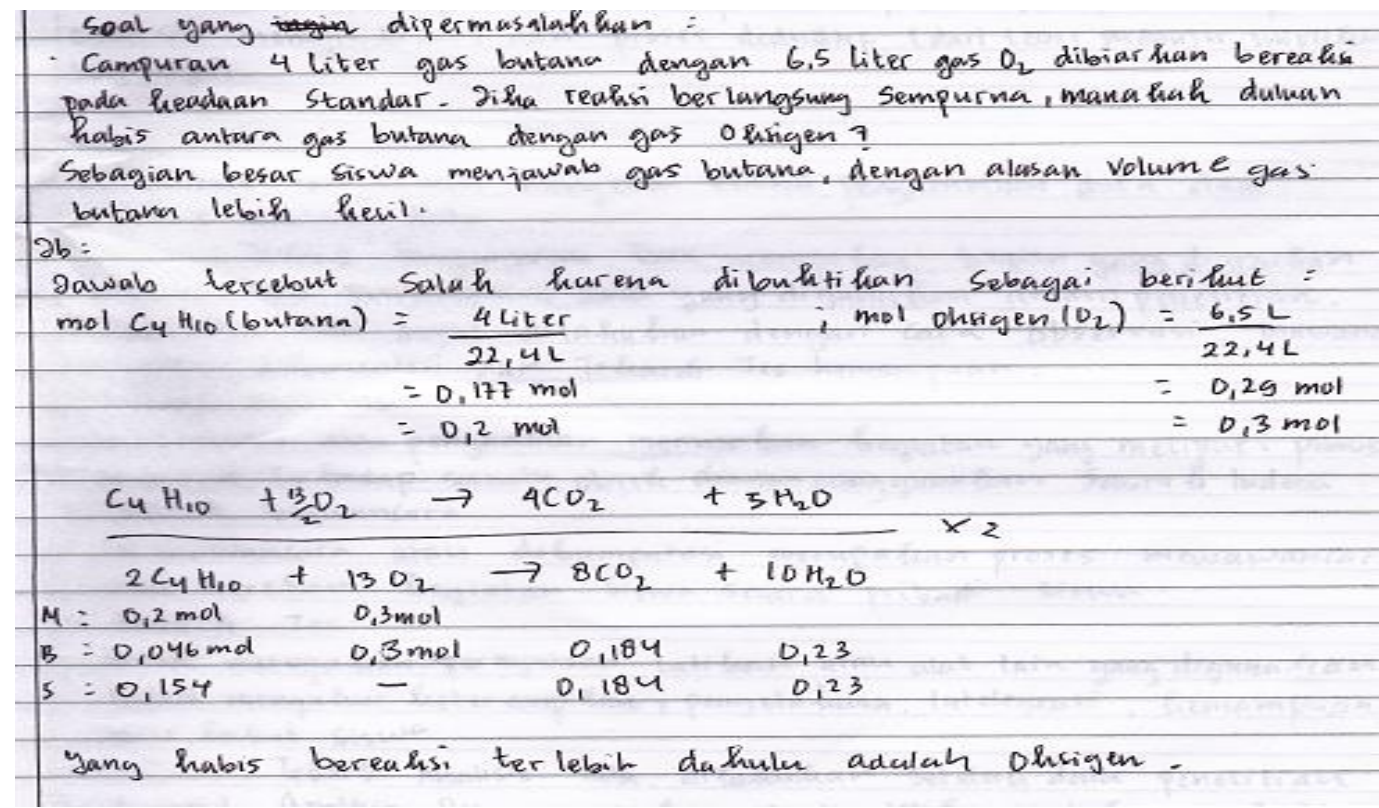

Berdasarkan data yang tersaji pada log book, sebagian besar mahasiswa menjawab Kasus 2 dengan langkah seperti di atas. Jawaban mahasiswa ini benar, namun langkah penyelesaian soal masih menghubungkan "keadaan standar - mol - koefisien", walaupun mahasiswa telah mampu menempatkan jumlah mula-mula zat pereaksi dalam soal.

Langkah penyelesaian soal tersebut dapat dilakukan dengan cara menggunakan prinsip "pada keadaan standar, perbandingan koefisien reaksi menunjukkan perbandingan volume gas-gas yang bereaksi". Jika mahasiswa menggunakan prinsip ini, maka dalam menyelesaikan Kasus 2 tidak perlu menghitung jumlah partikel zat cukup menggunakan perbandingan koefisien reaksi yang dikonversi ke perbandingan volume gas yang terlibat dalam reaksi.

Selanjutnya, sebagian besar mahasiswa mampu membuat rumusan masalah dan tujuan penelitian, menentukan populasi dan sampel, mengidentifikasi jenis data, cara menjaring data, dan menentukan teknik analisis data, terakhir mampu merumuskan judul penelitian dengan benar. Sebagian besar rumusan masalah judul ini mirip dengan rumusan yang ada pada proposal (dan atau) skripsi penelitian kimia pada umumnya.

Pada tahap Post PBL dilakukan pos tes untuk mengetahui perkembangan pengetahuan mahasiswa setelah mengikuti kegiatan pembelajaran PBL. Pos tes yang diberikan berupa kasus, juga tentang kesulitan siswa SMA memamahi pereaksi pembatas, hanya pernyataan soal dalam bentuk gambar. Berikut disajikan Kasus 3, bahan untuk pos tes. 


\section{KASUS:}

Pada jam pelajaran Kimia di kelas 1 SMA, Bu Nimur sedang menjelaskan konsep persamaan reaksi kimia. Tujuan pembelajaran yang diharapkan dicapai siswa adalah mampu tentang menggalang persatuan bangsa. Tujuan pembelajaran yang diharapkan dicapai adalah siswa mampu menerapkan hukum kekekalan massa pada persamaan reaksi. Pembelaajran dimulai dengan pelajaran sebelumnya, yaitu nama dan lambang unsur. Kemudian, bu Nimur menjelaskan cara menuliskan persamaan reaksi dan menyetarakannya. Pada awalnya semua siswa memperhatikan penjelasan BuNimur lengan serius. Setelah beberapa saat, ada beberapa siswa yang asik dengan kegiatannya sendiri. Setelah selesai menjelaskan, BuNimur jeminta siswa untuk mengajukan pertanyaan tentang materi yang baru dibahas. Ada seorang siswa yang mengajukan pertanyaan tetapi pertanyaannya tidak berkaitan dengan materi yang dibahas. Namun, Bu Nimur menjawab pertanyaan siswa tersebut dengan jelas dan terinci sampai siswa yang mengajukan pertanyaan memahami penjelasannya. Pada akhir pelajaran, bu Nimur memberi pos tes, sebagai berikut:

Suatu bejana tertutup berisi unsur $\mathrm{S}(\square)$ dan $\mathrm{O}_{2}(\infty)$ seperti terlihat pada gambar di bawah.

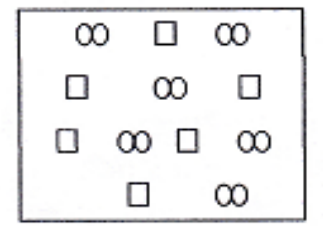

$$
\begin{aligned}
& a=\infty \\
& s=0 \\
& s=2 \\
& 0=6
\end{aligned}
$$

Jika persamaan reaksi antara $\mathrm{S}$ dan $\mathrm{O}_{2}$ adalah: $2 \mathrm{~S}(p)+3 \mathrm{O}_{2}(g) \rightarrow 2 \mathrm{SO}_{3}(g)$, maka gambar hasil reaksinya adalah ...

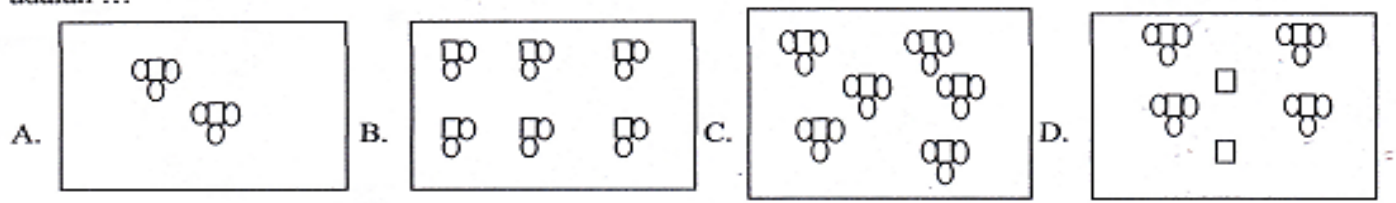

Setelah jawaban siswa diperiksa, diperoleh data sebagai berikut: siswa yang memilih pilihan $\mathrm{A}=8 ; \mathrm{B}=8 ; \mathrm{C}$ $=8 ; \mathrm{D}=8$ (jumlah siswa 32). Berdasarkan pola jawaban ini, masalah apa yang dapat anda teliti? Untuk menjawab ini, lakukan:

Sebagian besar $(82,8 \%)$ mahasiswa memilih pilihan jawaban A, 3\% memilih pilihan jawaban $\mathrm{C}$. Berdasarkan jawaban ini terlihat bahwa mahasiswa belum memahami hubungan antara jumlah zat mula-mula dengan persamaan reaksi. Kesalahan ini mengindikasikan bahwa kemampuan konseptual kimia mahasiswa masih rendah. Kondisi ini tentu akan mempengaruhi mahasiswa dalam merancang penelitian terkait dengan substansi.

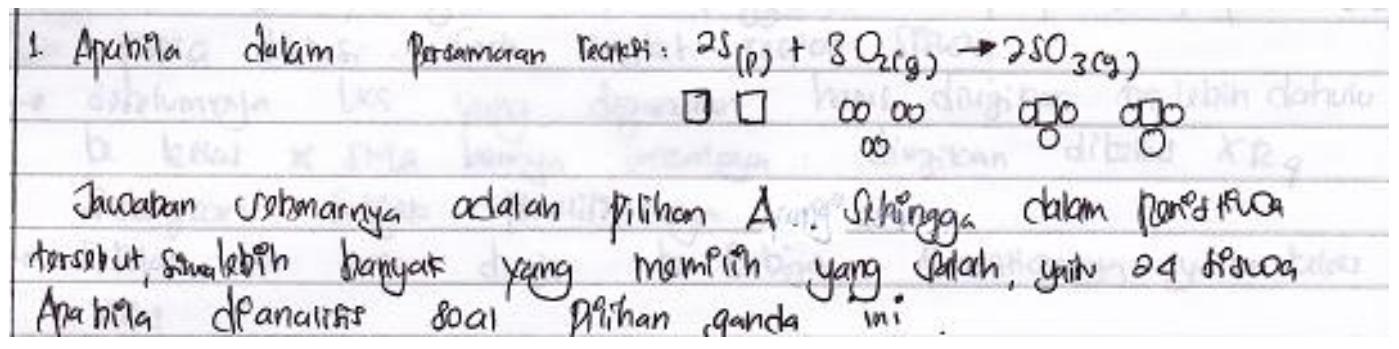

Walaupun demikian, sebagian besar mahasiswa telah mampu merumuskan masalah-judul penelitian dengan baik. Rumusan ini kemungkinan hanya meniru dari proposal yang mereka baca, namun sesungguhnya tidak memahami apa yang seharusnya mereka teliti.

Bagaimana pengaruh penggunaan metode belajar dalam
moningkatkan permahaman siswa tentang konsep persamaan
reaksi.




\section{Pengaruh perngganaan Metode bolajar dalam merningkat kan permahaman siswa terntang konsep persamaan reaksi}

\section{Kesimpulan}

Pengetahuan mahasiswa terkait dengan konsep kimia, terutama pereaksi pembatas masih rendah. Kegiatan pembelajaran PBL mampu memperbaiki pemahaman mahasiswa terkait dengan pereaksi pembatas pada level simbolik, namum gagal pada level mikroskopik (visualisasi).

Kesempatan yang diberikan kepada mahasiswa merumuskan sendiri tujuan pembelajaran dan cara mencapai tujuan tersebut dapat membuat mahasiswa fokus dalam mencari bahan ajar. Selanjutnya, tujuan ini divalidasi oleh teman sejawat melalui diskusi menjadikan mahasiswa lebih mampu merumuskan masalah penelitian, teknik pengumpulan data, teknik analisis data, dan merumuskan judul penelitian.

\section{Daftar Rujukan}

Belt, Simon T \& Evans, E Hywel \& McCreedy, Tom \& Overton, Tina L., \& Summerfield, Stephen (2002). A problem based learning approach to analytical and applied chemistry. University Chemistry Education; The Higher Education chemistry journal of the Royal Society of Chemistry; 6(2); $65-72$.

Bokonjic, Dejan, dkk (2013). Problem Based Learning.http://www.bhmedemanual.org/book/export/html/1 (diambil tanggal 8 Maret 2013).

Bradbeer, John (2010). Applying Problem-Based LearningIssues and Reflections on Theory and Practice. http://www.docstoc.com /? id=33889\&download=1 (diambil tanggal 8 Maret 2013).

Guerra, Aida \& Kolmos, Anette (2011).Comparing problem based learning models: Suggestions for their implementation. PBL Across the Disciplines: Research into Best Practice (Editor: John Davies, Erik de Graaff, dan Anette Kolmos (Eds.). Aalborg University Press; Denmark.

Halonen, Deana (2013). Problem Based Learning:A Case Study. Auspace.athabascau.ca/bitstream/2149/1519/3/Problem Based Learning.ppt (diambil tanggal 9 Maret 3013).

Hendarman. (2012). Kurikulum Pendidikan Guru Perlu Dievaluasi. (Kompas.com, 11 Juli 2012).

Hutton, Laura (tanpa tahun). Problem-Based Learning (and Assessment). http://www.docstoc.com/?doc_id=120643420\&download=1 (diambil tanggal 8 Maret 2013)

Mackenziea, Alison M. \& Johnstone, Alex H., \& Brown, R. Iain F. (2003). Learning from Problem Based Learning. University Chemistry Education. The Higher Education chemistry journal of the Royal Society of Chemistry. 7(1); 13 - 26. 
Jurnal Ilmiah Kanderang Tingang 10(1) (2019) l-1l ISSN 2087-166X

Januari-Juni 2019
Fakultas Keguruan dan Ilmu Pendidikan

Universitas Palangka Raya

https://chem-upr.education/ojs

Surapranata, Sumarna (2012). Perencanaan Kebutuhan Guru Pendidikan Dasar 2012. Makalah disampaikan padaKegiatan Analisis Validasi Instrumen Dokumen Pembinaan Karir PTKSD dan Analisis Perencanaan Kebutuhan Guru. Summer Hills Bandung. 31 Oktober -2 November 2012. 